Jurnal Ilmu Sosial dan Pendidikan (JISIP)

Vol. 5 No. 3 Juli 2021

Terakreditasi Peringkat 5 (No. SK: 85/M/KPT/2020)

e-ISSN : 2656-6753, p-ISSN: 2598-9944

DOI: 10.36312/jisip.v5i3.2237 /http://ejournal.mandalanursa.org/index.php/JISIP/index

\title{
Bentuk-Bentuk Modernisasi Pertanian di Desa Teamusu Kecamatan Ulaweng Kabupaten Bone Sulawesi Selatan
}

\author{
Bagas $^{1}$, Mansyur Radjab ${ }^{2}$, Sakaria ${ }^{3}$ \\ ${ }^{123}$ Prodi Magister Sosiologi, Fakultas Ilmu Sosial dan Ilmu Politik Universitas Hasanuddin
}

\begin{abstract}
Article Info
Article history:

Article Reseived : 19 July 2021

Publication: 20 July 2021
\end{abstract}

\section{Kata Kunci: \\ Modernisasi, Pertanian, \\ Masyarakat Petani}

Article Info
Article history:
Article Reseived : 19 July 2021
Publication: 20 July 2021

\section{Keyword}

Modernization, Agricultural, Farming Communities

\begin{abstract}
Abstrak
Modernisasi pertanian merupakan perubahan yang terjadi pada masyarakat dari berbagai fase dalam proses pertanian, mulai dari pola-pola tradisional dengan menggunakan alat-alat sederhana menuju penggunaan alatalat yang lebih modern. Penelitian ini bertujuan untuk menganalisis bagaimana bentuk-bentuk modernisasi pertanian yang ada di Desa Teamusu, Kecamatan Ulaweng, Kabupaten Bone, Sulawesi Selatan. Metode penelitian yang digunakan yaitu kualitatif deskriptif. Informan dalam penelitian ini adalah berbagai elemen masyarakat yang ada di Desa Teamusu. Teknik pengumpulan data pada penelitian ini diantaranya yaitu observasi, wawancara, dan dokumentasi. Hasil penelitian menunjukkan bahwa bentuk-bentuk modernisasi pertanian pada masyarakat Desa Teamusu meliputi berbagai aspek atau fase dalam prosesi pertanian, mulai dari pengelolaan lahan sampai pada fase pasca produksi mengalami perubahan yang signifikan. Namun, tidak semua lini mengalami perubahan secara total, hanya sebagian saja yang sudah tersentuh modernisasi. Adanya modernisasi tersebut memberikan dampak positif bagi masyarakat terutama pada efisiensi tenaga dan tingkat kesejahteraan masyarakat yang semakin membaik.
\end{abstract}

Modernization of agricultural is a change which occurs in the society from
various phases in the agricultural process, starting from using traditional simple
tools to using modern tools. This research aimed to analyze what forms of
agricultural modernization which exist in Teamusu Village, Ulaweng District,
Bone, South Sulawesi. The research method used was descriptive qualitative. The
informants of this research were some various elements of the society in Teamusu
Village. Data collection techniques in this research including observation,
interviews, and documentation. The results showed that the forms of agricultural
modernization in the Teamusu Village society included various aspects or phases
of the agricultural procession, from land management to the post-production
phase, which led to the significant changes. However, not all the lines had
changed completely, but only some of it that had been touched by modernization.
The existence of this modernization had a positive impact on the society,
especially on the energy efficiency and the level of society welfare which was
getting better.

This is an open access article under the Lisensi Creative Commons AtribusiBerbagiSerupa 4.0 Internasional

Corresponding Author:

\section{Bagas}

Prodi Magister Sosiologi, Fakultas Ilmu Sosial dan Ilmu Politik Universitas Hasanuddin

Email; bagasosiologi@gmail.com

\section{PENDAHULUAN}

Perubahan yang terjadi di masyarakat dilaterbelakangi oleh tuntutan zaman yang memaksa mereka untuk mengikuti alur perkembangan zaman (Togatorapi, 2017). Sehingga berbagai cara telah dilakukan agar kebutuhan-kebutuhan yang mereka inginkan bisa tercapai. 
Tanpa masyarakat memikirkan dampak yang akan ditimbulkan dari konsekuensi keputusankeputusan yang mereka buat. Termasuk dalam modernisasi pertanian yang mengakibatkan perubahan-perubahan banyak terjadi di masyarakat.

Modernisasi pertanian merupakan perubahan besar pada pola pertanian dari cara-cara yang tradisional menuju cara-cara yang lebih maju atau modern mencakup berbagai aspek yang meliputi, kelembagaan pertanian, teknologi pertanian, pengembangan sumber daya alam (SDA), dan regulasi (Rifkian, B. E. et al. (2017: 40).

Salah satu produk modernisasi yang pernah diterapkan dan berhasil yaitu revolusi hijau yang diterapkan di tahun 1960-an. Sebuah program akselerasi pertanian yang bertujuan meningkatkan efektivitas kerja petani. Keberhasilannya pernah menjadikan Indonesia sebagai negara yang swasembada beras dan menjadi negara pengekspor beras terbesar di dunia. Namun, tidak hanya implikasi positif itu, revolusi hijau juga ternyata menghadirkan perubahan pada polapola perilaku masyarakat tani dalam berbagai bidang, termasuk pada sisi sosial dan ekonomi (Prayoga et. al: 2019).

Hadirnya modernisasi dalam pertanian diharapkan memberikan angin segar bagi masyarakat. Modernisasi adalah suatu tuntutan bagi petani yang harus direalisasikan jikalau ingin menghasilkan hasil yang lebih baik dan maksimal. Karena modernisasi pertanian hadir dalam mendesain bagaimana masyarakat bisa mengalami peningkatan taraf hidup dan kesejahteraan. Selain itu, desain modernisasi pertanian yaitu dikenal dengan efektivitas dan efisiennya. Sehingga masyarakat yang dulunya hanya panen 2 kali dalam setahun, maka dengan adanya modernisasi ini, masyarakat bisa panen tiga kali atau bahkan sampai empat kali dalam setahun.

Menteri Pertanian Republik Indonesia (2021) mengatakan bahwa modernisasi pertanian dapat dilihat pada penggunaan metode budidaya yang lebih baik dan efektif, penerapan alat mesin pertanian dengan teknologi tepat guna dari mulai pengolahan lahan, pemanenan dan penanganan pasca panen, penggunaan benih unggul, pemupukan yang tepat guna dan mencukupi, penggunaan SDM pertanian yang lebih berkualitas, serta efisiensi penggunaan sumberdaya alam terutama air irigasi, sehingga keseimbangan lingkungan tetap terjaga.

Modernisasi pertanian muncul akibat kegagalan dari petani tradsional yang tidak bisa memberikan hasil yang maksimal. Sehingga muncul berbagai inovasi dalam menyelesaikan permasalahan yang dihadapi oleh masyarakat, yang tidak bisa memaksilkan fungsinya sebagai penghasil pertanian yang bisa menutupi berbagai kebutuhan masyarakat. Sebagaimana hasil penelitian yang dilakukan sebelumnya bahwa "tidak ada masyarakat yang membersihkan kebunnya menggunakan pacul, masyarakat hanya membabat dengan menggunakan parang, kemudian disemprot dengan herbisida. Sekarang serba canggih, tidak ada yang meggunakan pacul, hanya menggunakan herbisida. Pertama dengan menggunakan racun yang kuat (herbisida kontak) kemudian tahap selanjutnya racun Gramoxone yang berfungsi sebagai pembakar (herbisida sistemik). Sementara pupuk yang digunakan merupakan pupuk kimia dengan berbagai jenis" (Bagas, 2018).

Petani sekarang sudah mengalami kemajuan dari tahun ke tahun. Mulai dari hadirnya revolusi hijau yang digagas pada pemerintahan Orde Baru pada awal 1968an. Sebagaimana yang dikatakan oleh Yulia (2019) dalam Arifin (2001) bahwa pencanangan Revolusi Hijau ini bertujuan sebagai sarana yang akan meningkatkan produksi pangan, khususnya produksi beras secara luar biasa, dengan asumsi bahwa dengan kelimpahan produksi maka akan meningkatkan kesejahteraan rakyat petani. Melalui Program-program bimbingan massal (bimas), intensifikasi massal (inmas) kemudian dikembangkan kegiatan melalui kelompok tani seperti intensifikasi khusus (insus) yang juga sebagai perangkat untuk membantu petani meningkatkan produktivitas usaha taninya telah diadakan misalnya, dalam hal kelembagaan, penyuluhan, kredit, pemasaran dan koperasi dengan harapan dapat merubah tingkat kehidupan petani.

Berdasarkan runutan pembahasan di atas, peneliti tertarik untuk melakukan penelitian mengenai bagaimana bentuk-bentuk modernisasi pertanian yang ada di Desa Teamusu, Kecamatan Ulaweng, Kabupaten Bone, Sulawesi Selatan. 
Tujuan dari penelitian ini yaitu untuk menganalisis bagaimana bentuk-bentuk modernisasi pertanian di Desa Teamusu, Kecamatan Ulaweng, Kabupaten Bone, Sulawesi Selatan.

\section{METODE PENELITIAN}

Penelitian ini menggunakan tipe penelitian deskriptif dengan menggunakan metode penelitian kualitatif. Penelitian ini bertujuan untuk mendeskripsikan bagaimana bentuk-bentuk modernisasi pertanian yang ada di Desa Teamusu, Kecamatan Ulaweng, Kabupaten Bone, Sulawesi Selatan.

Lokasi penelitian berada di Bone bagian Barat. Pada masyarakat daerah tersebut, mayoritas masyarakat berprofesi sebagai petani yaitu sebesar $87,12 \%$. Kemudian, daerah tersebut terdiri dari dataran rendah dan dataran tinggi, sehingga komoditi pertanian daerah tersebut beragam, hal itulah yang menjadi acuan peneliti untuk menjadikan lokasi tersebut sebagai objek penelitian. Adapun yang menjadi kefokusan peneliti yaitu mulai dari pembukaan lahan, penanaman, pemeliharaan, pemanenan, dan pasca produksi.

Pemilihan lokasi dilakukan dengan sengaja (purposive sampling) dengan dasar pertimbangan bahwa daerah ini dalam 5 tahun terakhir telah mengalami perubahan dalam berbagai dimensi di masyarakat, termasuk dalam proses penanaman jagung atau padi, tidak lagi menggunakan sistem gotong royong, hal tersebut sebagai konsekuensi dari adanya modernisasi dalam bidang pertanian.

Teknik pengumpulan data dilakukan dengan tiga cara, yaitu: observasi, wawancara, dan dokumentasi. Wawancara dilakukan kepada 8 orang, 2 orang perangkat desa, 2 orang akademisi, 1 orang kelompok tani, 1 orang tokoh pemuda, 1 orang ibu rumah tangga, dan 1 orang petani. Observasi dilakukan dengan mengamati keadaan lokasi penelitian, perilaku masyarakat, mengamati masyarakat dalam mengelola lahannya, dan ikut terlibat dalam kegiatan pertanian masyarakat. sementara dokumentasi pada penelitian ini, yaitu dengan melihat hal-hal yang dianggap penting dan mendukung kegiatan penelitian.

Data yang didapatkan di lapangan diolah dengan beberapa tahapan yaitu, reduksi data, penyajain data, dan penarikan kesimpulan.

\section{HASIL dan PEMBAHASAN}

Modernisasi Pertanian memberikan pengaruh yang signifikan di masyarakat, tidak terkecuali di Desa Teamusu Kecamatan Ulaweng Kabupaten Bone yang menjadi lokasi penelitian penulis. Hadirnya modernisasi tersebut memberikan angin segar bagi masyarakat. Pasalnya, banyak hal-hal yang kemudian memudahkan pekerjaan masyarakat. Tidak hanya memudahkan akan tetapi pekerjaan masyarakat menjadi efisien berkat adanya penemuanpenemuan tersebut.

Perubahan sosial yang terjadi di masyarakat tidak hanya menyentuh pada masyarakat perkotaan saja, akan tetapi sampai pada masyarakat pedesaan, tidak terkecuali Desa Teamusu yang menjadi objek penelitian penulis. Kehidupan masyarakat yang ada di desa telah mengalami berbagai perubahan-perubahan sebagai akibat dari globalisasi yang tidak bisa dibendung. Perubahan tersebut, bagian dari konsekuensi-konsekuensi yang tidak bisa ditolak oleh masyarakat.

Pembangunan pertanian yang selama ini dirasakan oleh masyarakat merupakan gagasan yang bermula pada era 80 -an sebagai bentuk kesadaran berbagai elemen masyarakat atas kondisi yang dialami oleh bangsa Indonesia dalam bidang pertanian. Oleh karena itu, lahirlah gagasan dalam penggunaan sistem tradisional menuju sistem yang modern. Strategi-strategi tersebut memberikan hasil yang memuaskan masyarakat, yang berhasil swasembada beras beberapa tahun setelah gagasan itu diluncurkan.

Perubahan yang terjadi pada masyarakat petani terlihat dengan jelas, hal ini dapat dilihat pada tata cara bertani masyarakat yang mengalami perubahan yang drastis. Seperti penggunaan tenaga hewan yang digantikan dengan tenaga mesin dalam membajak sawah, penggunaan pupuk 
kandang yang digantikan dengan pupuk kimia yang serba praktis, dan berbagai modernisasimodernisasi yang lain dalam bidang pertanian yang memberikan kemudahan-kemudahan masyarakat dalam bertani. Untuk mengetahui lebih jelasnya, perubahan-perubahan yang terjadi pada masyarakat Desa Teamusu mengenai tata cara bertani dari sistem tradisional menuju sistem yang lebih modern, lihat tabel sebagai berikut:

\begin{tabular}{|c|c|c|c|c|c|}
\hline \multirow{2}{*}{ No } & \multirow{2}{*}{$\begin{array}{c}\text { Tahap-tahap } \\
\text { bertani }\end{array}$} & \multicolumn{2}{|c|}{ Jagung } & \multicolumn{2}{|l|}{ Padi } \\
\hline & & Tradisional & Modern & Tradisional & Modern \\
\hline 1. & $\begin{array}{l}\text { Pembukaan } \\
\text { lahan }\end{array}$ & $\begin{array}{l}\text { Linggis, Pacul, } \\
\text { Cangkul, } \\
\text { Kapak, Parang, } \\
\text { dibakar, } \\
\text { Tenaga } \\
\text { Hewan. }\end{array}$ & Senso & $\begin{array}{l}\text { Cangkul, Tenaga } \\
\text { Hewan, dan diijak } \\
\text { kemudian didorong } \\
\text { dengan kayu }\end{array}$ & Mesin Traktor \\
\hline 2. & Penanaman & $\begin{array}{l}\text { Bibit } \\
\text { tradisional, } \\
\text { Subbe Parasa } \\
\text { (Pacul } \\
\text { Panjang), dan } \\
\text { menggunakan } \\
\text { sistem gotong } \\
\text { royong }\end{array}$ & $\begin{array}{l}\text { Penggunaan } \\
\text { bibit unggul } \\
\text { (Hibrida), } \\
\text { Mesin, Buruh } \\
\text { Tanam }\end{array}$ & $\begin{array}{l}\text { Secara manual } \\
\text { dengan tangan, bibit } \\
\text { lokal }\end{array}$ & $\begin{array}{l}\text { Mesin } \\
\text { Paddenreng, } \\
\text { Cappo, dan } \\
\text { Tabur, } \\
\text { penggunaan } \\
\text { bibit unggul }\end{array}$ \\
\hline 3. & Pemeliharaan & $\begin{array}{l}\text { Pupuk } \\
\text { Kandang, } \\
\text { Disubbe } \\
\text { (membersihka } \\
\text { n gulma } \\
\text { dengan pacul), } \\
\text { Pagar keliling } \\
\text { dengan batu, } \\
\text { Mangampi } \\
\text { (menjaga } \\
\text { malam dari } \\
\text { serangan babi) }\end{array}$ & $\begin{array}{l}\text { Pupuk Kimia, } \\
\text { Pupuk Cair, } \\
\text { Strum, } \\
\text { Pestisida (anti } \\
\text { gulma) }\end{array}$ & $\begin{array}{l}\text { Pupuk kandang, } \\
\text { Sprayer manual, } \\
\text { Sepe' (irigasi biasa) } \\
\text { Maddongi (menjaga } \\
\text { secara langsung dari } \\
\text { seragangan burung } \\
\text { pipit }\end{array}$ & $\begin{array}{l}\text { Pupuk Kimia, } \\
\text { Pupuk Cair, } \\
\text { Sprayer } \\
\text { electrik, Sepe } \\
\text { (Irigasi dengan } \\
\text { menggunakan } \\
\text { Semen), } \\
\text { Mesin, dan } \\
\text { Pestisida }\end{array}$ \\
\hline 4. & Pemanenan & $\begin{array}{l}\text { Masseppe } \\
\text { (dibuka satu } \\
\text { per } \\
\text { dengan satu } \\
\text { tangan), } \\
\text { dirontok } \\
\text { menggunakan } \\
\text { tangan, } \\
\text { dimasukkan } \\
\text { dalam karung } \\
\text { kemudian } \\
\text { dipukul } \\
\text { dengan kayu, } \\
\text { digotong ke } \\
\text { rumah, skala } \\
\text { konsumsi }\end{array}$ & $\begin{array}{l}\text { Menggunaka } \\
\mathrm{n} \text { buruh } \\
\text { panen, } \\
\text { perontokan } \\
\text { dengan } \\
\text { mesin, skala } \\
\text { industri, } \\
\text { dingkut } \\
\text { dengan } \\
\text { menggunakan } \\
\text { jasa ojek } \\
\text { motor dan } \\
\text { mobil } \\
\text { dompeng. }\end{array}$ & $\begin{array}{l}\text { Enggala } \\
\text { (menggunakan } \\
\text { pisau yang desain } \\
\text { khusus), dipotong } \\
\text { dengan r sabit } \\
\text { kemudian disampa } \\
\text { (dibanting diatas } \\
\text { kayu), hasil panen } \\
\text { disimpan r di } \\
\text { rakkiang (cadangan } \\
\text { makanan), hasil } \\
\text { panen digotong ke } \\
\text { rumah }\end{array}$ & $\begin{array}{l}\text { Mengguanaka } \\
\mathrm{n} \text { mesin } \\
\text { perontok, hasil } \\
\text { panen } \\
\text { menggunakan } \\
\text { jasa buruh } \\
\text { ojek motor dan } \\
\text { dompeng. }\end{array}$ \\
\hline
\end{tabular}




\begin{tabular}{|c|l|l|l|l|l|}
\hline & $\begin{array}{l}\text { Disimpan di } \\
\text { Rakkiang (atas } \\
\text { rumah) / di } \\
\text { gudang } \\
\text { 5. }\end{array}$ Pasca \\
Produksi & $\begin{array}{l}\text { sebagai } \\
\text { cadangan } \\
\text { makanan }\end{array}$ & Dijual semua & $\begin{array}{l}\text { disimpan dijuan dan } \\
\text { Rakkiang (atas } \\
\text { rumah) / di gudang } \\
\text { sebagai cadangan } \\
\text { makanan }\end{array}$ & $\begin{array}{l}\text { disimpan } \\
\text { sebagian untuk } \\
\text { cadangan } \\
\text { makanan dan } \\
\text { bibit }\end{array}$ \\
\hline
\end{tabular}

Sumber : Bagas, 2021

Perubahan yang terjadi pada masyarakat merupakan suatu hal tidak bisa dihindari oleh masyarakat, karena bagian dari dinamika pertanian dan kebutuhan masyarakat yang memaksa masyarakat untuk melakukan suatu modernisasi dalam masing-masing bidang pekerjaan masyarakat. Modernisasi yang terjadi pada masyarakat tani di Desa Teamusu meliputi berbagai fase, diantaranya sebagai berikut:

\section{Pembukaan lahan}

Pembukaan lahan merupakan fase awal yang dilakukan dalam prosesi bertani. Pembukaan lahan yang dilakukan oleh masyarakat, dahulu menggunakan peralatan yang sederhana. Misalnya pada masyarakat petani jagung, dahulu dalam membuka lahan, masyarakat menggunakan parang atau kapak untuk menebang pohon. Setelah itu, baru menuju ketahap selanjutnya yaitu ranting-ranting dipotong kecil kemudian ditunggu sampai kering kemudian dibakar.

Tenaga masyarakat begitu banyak yang terkuras karena peralatan yang mereka gunakan cukup menguras tenaga, sehingga pekerjaan tersebut lama diselesaikan. Setelah memasuki era modernisasi, pekerjaan tersebut yang semula menggunakan parang atau kapak, sekarang masyarakat dimudahkan dengan menggunakan mesin pemotong kayu (senso). Setelah tahap itu selesai, dalam membasmi gulmanya sebelum memasuki musim tanam, masyarakat menggunakan pacul atau cangkul.

Proses penyangkulan membutuhkan waktu dan tenaga ekstra karena sepenuhnya dikerjakan secara manual. Arah baru pertanian telah tiba, dahulu dalam menggemburkan tanah menggunakan linggis ketika musim kemarau telah tiba, tanah yang kering kemudian dibalik dengan menggunakan linggis. Selain itu, ada juga masyarakat yang menggunakan tenaga hewan dalam menggemburkan lahannya. Dewasa ini, cara-cara tersebut tidak lagi dijumpai di masyarakat, terutama di Desa Teamusu yang menjadi lokasi penelitian penulis. Masyarakat lebih memilih menggunakan mesin Traktor. Selian itu, masyarakat juga menggunakan Herbisida dalam membasmi gulma, sehingga pekerjaan masyarakat lebih efektif dan efisien.

Pada petani padi, dahulu dalam membuka atau mengolah lahannya masyarakat menggunakan cangkul dan tenaga hewan. Sekalipun pekerjaan tersebut tidaklah mudah, namun masyarakat tetap menjalankan rutinitas pekerjaannya di sawah. Pada metode tradisional tersebut, masyarakat tidak bisa membuka lahan banyak, hanya skala rumah tangga saja, karena pekerjaannya yang membutuhkan tenaga ekstra.

Setelah sekian lama, tenaga hewan tersebut digantikan oleh mesin traktor. Hadirnya modernisasi tersebut, memberikan angin segar bagi petani. Pasalnya, dengan adanya mesin tersebut, masyarakat bisa membuka lahan seluas mungkin. Oleh karena itu, tingkat kesejahteraan masyarakat mulai ada peningkatan. Hasil panen tersebut, tidak hanya dikonsumsi atau disimpan di kolom rumah, akan tetapi merambah pada skala jual.

\section{Penanaman}

Penanaman merupakan fase kedua yang menjadi salah satu fase terpenting dalam pertanian. Pada fase ini, pemilihan benih sangat diperlukan untuk mendapatkan hasil yang maksimal. Masyarakat dahulu, tidak memperhatikan perihal benih tersebut, padahal itu merupakan kunci kesuksesan awal bagi petani. Masyarakat hanya menggunakan benih dari hasil panen, sehingga varietas yang dihasilkan kurang bagus dan berpengaruh terhadap hasil panen selanjutnya. 
Kesadaran masyarakat terhadap benih atau bibit unggul sudah ada, bahkan pada petani jagung, tidak lagi menggunakan bibit lokal, bahkan masyarakat rela mengeluarkan dana besar untuk membeli bibit unggul. Masyarakat selain berprofesi sebagai petani, juga berprofesi sebagai peneliti, misalnya penggunaan beberapa jenis bibit, petani bisa membedakan bibit yang memiliki kualitas baik. Oleh karena itu, kesadaran petani dalam menggunakan bibit unggul itu semakin tinggi, bahkan bibit pembagian dari pemerintahpun mereka kadang tidak menanamnya karena kualitasnya yang tidak maksimal.

Pada petani jagung, dalam proses penanaman tidak banyak yang berubah, hingga saat ini masyarakat masih menggunakan pacul yang sudah didesain khusus untuk menanam. Hanya sebagian kecil masyarakat yang menggunakan mesin penanam, karena kondisi lahan yang tidak mendukung. Selain itu, karena lahan masyarakat yang semakin banyak, sehingga masyarakat tidak bisa bergotong royong. Oleh karena itu, sebagai solusi masyarakat menggunakan jasa buruh tanam, karena tidak bisa menunggu lama. Ketika musim hujan sudah mulai, masyarakat berlomba-lomba dalam menanam, sehingga tidak ada waktu untuk saling membantu sesama.

Sementara pada petani padi, dahulu masyarakat tidak mengenal banyak metode dalam penanaman, kebanyakan petani hanya menggunakan metode mattaneng (menanam secara manual), hanya sebagian kecil yang menabur langsung di sawah. Seiring perkembangan waktu, petani menemukan sebuah alat yang digunakan untuk menanam. Penemuan alat tersebut, memberikan kemudahan bagi petani, karena tidak membutuhkan tenaga yang banyak dan pengerjaannya mudah bagi masyarakat. Selain itu, kehadiran alat tersebut juga menjadi berkah bagi sebagian masyarakat, karena alat tersebut tidak semua masyarakat bisa operasikan sehingga menjadi sumber penghasilan bagi masyarakat. Masyarakat yang tidak bisa mengoperasikan atau tidak punya mesin tersebut, mereka hanya menggunakan jasa buruh paddenreng-denreng.

\section{Pemeliharaan}

Pemeliharaan merupakan salah satu fase yang harus diperhatikan dengan baik, karena jikalau pada fase ini tidak dimaksimalkan maka hasilnya bisa saja tidak sesuai dengan ekspektasi. Oleh karena itu, pada tahap ini, ada beberapa hal yang harus diperhatikan, yaitu sebagai berikut:

\section{a. Pengairan}

Setelah proses penanaman selesai, hal utama yang harus diperhatikan yaitu terkait masalah pengairan. Pada tanaman padi, setelah penanaman tidak langsung membutuhkan air, akan tetapi harus dikosongkan dulu atau airnya sedikit, supaya bisa memaksimalkan perkembangan akar pada tanaman tersebut. Oleh karen itu, irigasi menjadi hal yang penting pada petani padi, karena dengan adanya irigasi petani bisa mengatur kapan jadwal pengairan pada sawahnya.

Sumber air di Desa Teamusu tidak sama seperti desa yang lain, di Desa Teamusu memiliki sumber air yang melipah, sehingga menjadi berkah buat petani padi. Perubahan yang terjadi hanya pada tataran materi pada irigasi tersebut. Dahulunya, materi dari irigasi tersebut hanya tanah dan batu yang tersusun rapi, air banyak yang meresap sehingga air yang sampai di lahan yang jauh dari sumber air, biasa tidak maksimal.

Berdasarkan permasalahan tersebut, sehingga lahirlah suatu inisiasi dari masyarakat agar membuat irigasi yang terbuat dari bahan yang mengatasi permasalahan itu. Irigasi yang didesain khusus untuk pengairan sawah yang mampu membuat perubahan pada kondisi pengairan pada sawah masyarakat. Sampai saat ini, petani bisa menanam padi selama 2 kali dalam setahun, irigasi tersebut menjadi berkah buat petani.

Fenomena yang terjadi di masyarakat Desa Teamusu, khususnya masyarakat yang memiliki lahan sawah padi, setelah munculnya komoditi jagung masyarakat banyak yang mengganti jenis tanamannya dari padi menjadi jagung. Oleh karena itu, sampai saat ini, irigasi yang dibuat oleh masyarakat bisa menyuplai petani sawah padi dan jagung. Adapun untuk lahan dataran tinggi, hanya menggunakan air hujan saja. 


\section{b. Pemupukan}

Pemupukan merupakan salah satu kunci yang harus diperhatikan oleh petani. Pasalnya, kondisi kesuburan tanah semakin hari semakin mengalami perubahan sebagai akibat manajemen pertanian yang tidak pro lingkungan. Pada masyarakat dahulu, sekalipun tidak menggunakan pupuk, tanaman tetap tumbuh dengan subur. Kalaupun menggunakan pupuk, bahan yang digunakan yaitu dari alam sehingga kesuburan tanah semakin terjaga. Namun, pola perilaku masyarakat dalam bertani mengalami perubahan, massyarakat tidak lagi bergantung dengan alam, karena prosesnya yang tidak mudah dan menyita banyak waktu. Selain itu, masyarakat juga tidak bisa membuka lahan luas karena keterbatasan pupuk kandang yang susah.

Seiring berjalannya proses tersebut, karena adanya tuntutan dalam berbagai lini dan hasil tidak lagi sesuai dengan ekspektasi masyarakat, maka lahirlah penggunaan pupuk kimia yang menjadi primadona petani. Penggunaan pupuk kimia memberikan angin segar bagi petani karena memudahkan masyarakat dan hasilnya sangat memuaskan petani. Tidak hanya terbatas pada penggunaan pupuk kimia dalam bentuk padat, akan tetapi sudah ada masyarakat yang menggunakan pupuk organik cair, sebagai bentuk pengembangan yang pro dengan lingkungan.

\section{c. Penyiangan dan Penyemprotan}

Masyarakat dalam membersihkan gulma yang ada dalam sawah atau kebunnya menggunakan peralatan seadanya seperti pacul, cangkul, sabit, dan bahkan ada masyarakat yang menggunakan tangannya. Dahulu semua dilakukan secara manual, bahkan jika petani kewalahan dalam membersihkan gulmanya, petani menyewa buruh dalam membantu menyelesaikan pekerjaannya tersebut.

Dewasa ini, proses penyiangan tidak lagi dilakukan secara manual, akan tetapi semuanya dilakukan dengan mudah tanpa tenaga ekstra. Saat ini, penyiangan digantikan dengan penggunaan pestisida yang mampu membasmih gulma-gulma yang dapat menghambat pertumbuhan tanaman. Penggunaan sprayer saat inipun mengalami perkembangan yang dinamis, dahulu masyarakat hanya mengenal sprayer manual, namun sekarang dalam membasmi hama dan gulma, masyarakat sudah ada yang menggunakan sprayer elektrin dan sprayer mesin. Penggunaan sprayer tersebut sangat ekonomis, pasalnya tenaga yang dibutuhkan tidak harus ekstra, begitupula luas dan jangkauannya berbebeda dengan sprayer manual, sehingga dapat menghemat pestisida petani.

\section{d. Penjagaan}

Tanaman yang sudah berbuah harus diperhatikan, karena banyak hewan yang mengintai, seperti pada tanaman padi, musuhnya adalah hewan pemakan biji-bijian. Begitu pula pada tanaman jagung, hamanya berupa Anjing dan Babi. Oleh karena itu, petani harus menjaga baik-baik tanamannya. Pada tanaman padi, petani menjaga langsung dari predator tersebut, yaitu dimulai dari pagi hingga sore hari. Namun, sekarang sudah dimudahkan masyarakat karena petani banyak yang menggunakan pestisida untuk membasmi hewan tersebut, cukup disemprot saja buahnya, hewan yang memakannya langsung tewas. Sementara pada tanaman Jagung, dahulu petani sebelum memasuki musim tanam, yaitu tepatnya pada musim kemarau, masyarakat bergotong royong dalam memburuh Babi. Sehingga jika memasuki musim tanam predator tersebut sudah berkurang. Pada saat Jagung sudah berbuah, masyarakat dahulu selalu mangampi (menjaga kebun di waktu malam). Namun, saat ini masyarakat sudah memilih cara dalam menjaga kebunnya tanpa datang mangampi, yaitu petani memasang strum disekeliling kebunnya. Strategi itu sangat ampuh, hama tersebut tidak berani datang, karena jikalau tersentuh kabel tersebut maka langsung tersengat listrik.

\section{Pemanenan}

Pemanenan merupakan momen yang paling ditunggu-tunggu oleh petani, setelah menunggu beberapa bulan dengan melalui beberapa fase. Pada fase ini merupakan tahap akhir dari budidaya tanaman. Pemanenan yang dilakukan oleh masyarakat dari dahulu sampai 
sekarang mengalami perubahan. Misalnya pada tanaman Jagung, sebelum masuknya mesin perontok, masyarakat menggunakan alat berupa kayu, kemudian jagung dimasukkan dalam karung lalu dipukul karung tersebut sampai rontok bijinya. Selain itu, masyarakat ada juga yang merontoknya dengan menggunakan jari-jari tangan.

Sementara pada tanaman berupa padi, proses pemanenan pada generari pertama yaitu mengngala dengan menggunakan pisau yang sudah didesain khusus, kemudian dipotong satu per satu dari batangnya. Sementara pada generasi kedua yaitu massampa, masyarakat menggunakan sabit untuk memotong kemudian dikumpulkan dalam tenda-tenda, setelah itu padi tersebut dibanting diatas kayu. Proses tersebut membutuhkan tenaga yang ekstra, karena harus mengumpulkan tenaga yang banyak untuk membanting padi tersebut agar biji-bijinya bisa rontok semua. Pada generasi ketiga, selangkah lebih maju dibandingkan metode massampa, yaitu menggunakan roda-roda yang sudah didesain khusus. Proses pemotongan pada generasi kedua sama, hanya saja yang berbeda yaitu pada proses perontokan dengan menggunakan roda-roda, batang padi disimpan diatas roda-roda tersebtut yang sudah ditancapkan paku kemudian dikayuh. Generasi keempat yaitu Maddaros (semi modern) yang sementara berlangsung saat ini di Desa Teamusu pemotongan masih menggunakan sabit, kemudian dikumpulkan ke satu titik dan perontokan menggunakan mesin yang diorganisir oleh beberapa orang.

\section{Pasca Produksi}

Pasca produksi merupakan fase terakhir dari berbagai rangkaian yang dilakukan oleh petani Jagung setelah menunggu kurang lebih 4 bulan, pada fase ini paling ditunggu-tunggu oleh masyarakat petani. Setelah pemanenan dilakukan, tidak lagi disimpan sebagai cadangan makanan. Karena jenis bibit yang ditanam tidak bisa tahan lama sehingga semua hasil panen dijual oleh masyarakat. Berbeda dengan jenis bibit yang ditanam sebelum menjamurnya bibit unggul tersebut, masyarakat menggunakan bibit lokal yang tahan lama. Namun, bibit lokal tersebut dari segi produktivitas hasil pertanian itu sangat rendah, sehingga masyarakat lebih memilih bibit unggul. Sementara pada petani Padi, tidak ada yang berubah kebanyakan hasil panennya disimpan untuk dikonsumsi dan biasanya jika ada kebutuhan, baru dijual sebagaian. Analisis Hasil Penelitian Menggunakan Teori Lima Tahap Pembangunan W.W. Rostow

Rostow dalam bukunya yang terkenal The Strages of Economic Growth, A NonCommunist Manifesto yang mengurai teorinya yang berkaitan dengan proses pembangunan dalam sebuah masyarakat. Pada intinya bahwa pembangunan itu merupakan proses yang bergerak dalam sebuah garis lurus, yakni dari masyarakat yang terbelakang ke masyarakat yang maju (Budiman, 2000).

Perubahan yang terjadi pada masyarakat di Desa Teamusu membutuhkan waktu yang panjang dengan berbagai rentetan yang harus dilewati, mulai dari pertanian secara tradisional menuju pertanian yang sudah tersentuh dengan modernisasi dari berbagai bidang. Hal demikian, seiring dengan perkembangan pengetahuan masyarakat. Pengetahuan masyarakat terkait bidang pertanian, bisa dilihat bagaimana keseharian masyarakat sebagai subjek dalam pertanian yang menginternalisasikan ilmu pengetahuannya dalam bercocok tanam.

Pada awalnya masyarakat di Desa Teamusu dalam bercocok tanam, masih sangat sederhana mulai dari penggunaan alat-alat yang serba tradisional, kepercayaan-keprecayaan tentang kekuatan yang berada dluar manusia yang menguasai masyarakat, sehingga segala sesuatunya terhambat dan masyarakat tidak bisa memproduksi banyak, produksi hanya untuk konsumsi rumah tangga saja.

Perubahan yang terjadi pada masyarakat sekalipun sangat lambat namun terus mengalami perkembangan. Produksi hasil pertaniannya sudah mulai diinvestasikan pada sektor-sektor yang lebih produktif, misalnya pada sektor pendidikan. Karena masyarakat sudah memahami bahwa pendidikan merupakan aset yang berharga bagi mereka. Sampai saat ini, rata-rata pendidikan Sekolah Menengah Pertama, juga banyak yang sudah mengenyam pendidikan Sekolah Menengah Atas, bahkan sudah banyak yang lanjut kuliah tingakt Sarjan dan Magister. Masyarakat berharap hasil pendidikan tersebut, dikemudian hari mereka bisa nikmati dan 
bentuk pengaplikasian dalam berbagai bidang, termasuk pada bidang pertanian yang masyarakat sangat butuhkan.

Kesadaran masyarakat semakin tumbuh, misalnya dalam hal penggunaan alat-alat yang memberikan kemudahan, begtipula penggunaan pupuk kimia masyarakat lebih memprioritaskan karena dari segi hasil bisa maksimal. Selain itu, masyarakat juga sudah mulai meluaskan lahannya agar hasilnya juga semakin banyak dan produksinya tidak lagi terbatas konsumsi rumah tangga, tapi bisa jadi skala industri atau ekspor.

Keberhasilan masyarakat petani semakin menonjol, setelah modernisasi terjadi dalam berbagai lini, misalnya penggunaan bibit unggul, penggunaan mesin-mesin, adanya akses jalan tani, irigasi, dan berbagai modernisasi yang lain. Modernisasi dalam bidang peratanian di Desa Teamusu selain memberikan perubahan dalam aspek ekonomi, dimana pada masyarakat kesejahteraannya semakin membaik, modernisasi tersebut juga memberikan angin segar bagi petani dan sebagian masyarakat, Karena produktivitas semakin tinggi sehingga petani tidak bisa menyelesaikan pekerjaannya secara sendiri sehingga sebagai solusi, mencari buruh dalam membantu menyelesaikan pekerjaanya. Modernisasi pertanian mampu melahirkan pembagianpembagian kerja di masyarakat. Misalnya pembagian kerja pada fase pembukaan lahan, ada masyarakat yang memiliki mesin traktor yagn berperan sebagai buruh, aspek penanaman, ada kelompok-kelompok tertentu yang menjadi buruh tanam, begitupula ketika pemanenan pemilik lahan menyewa orang-orang untuk membantu panen, kemudian hasil panen tersebut, diangkut ke rumah atau dititik tertentu dengan menggunakan jasa Ojek atau Mobil Dompeng (mobil yang didesain khusus untuk mengangkut hasil pertanian).

\section{KESIMPULAN}

Mayoritas pekerjaan masyarakat di Desa Teamusu yaitu petani mencapai angka 87,12\%. Berdasarkan data tersebut, ketergatungan hidup masyarakat dengan pertanian sangat tinggi. Oleh karena itu, inovasi-inovasi dalam bidang pertanian sangat dibutuhkan masyarakat dalam menunjang pekerjaannya. Dengan adanya modernisasi-modernisasi tersebut, memberikan pengaruh pada kondisi kesejahteraan masyarakat.

Modernisasi pertanian pada masyarakat Desa Teamusu menyentuh berbagai fase, mulai dari pembukaan lahan sampai proses pemanenan. Sebelum masuknya mesin traktor pengolaan lahan menggunakan alat yang sederhana seperti cangkul dan tenaga hewan, begitupula bibit yang digunakan, sekarang mayoritas masyarakat menggunakan bibit unggul baik petani jagung maupun petani padi. Karena hasilnya jauh lebih memuaskan masyarakat dibandingkan menggunakan bibit lokal atau bibit tradisional.

\section{SARAN}

Ada beberapa saran untuk penelitian selanjutnya yaitu diantaranya cakupan wilayah lebih luas lagi misalnya skala kecamatan atau kabupaten, analisis penelitian dengan mengunakan teori lain yang relevan, dan yang terakhir yaitu terkait pengaruh modenisasi pertanian terhadap pengentasan kemiskinan melalui pemberdayaan Janda sebagai buruh panen.

\section{UCAPAN TERIMA KASIH}

Penulis meyakini bahwa artikel ini tidak akan selesai tanpa adanya doa dan dukungan dari keluarga berserta Dosen Pembimbing. Oleh karena itu, penulis mengucapkan banyak terima kasih kepada orangtua yang telah memberikan support kepada penulis. Begitupula ucapan terima kasih penulis berikan kepada pemerintah Desa Teamusu yang telah memberikan izin untuk pengambilan data dan kesediaanya menjadi informan pada penelian yang penulis laksanakan. Semoga Allah 㧛 memudahkan segala urusan masyarakat.

\section{DAFTAR PUSTAKA}

Bagas. 2018. Gotong Royong dalam Masyarakat Petani Studi Tentang Tergerusnya Gotong Royong di Desa Tadang Palie Kecamatan Ulaweng Kabupaten Bone. Skripsi, Universitas Hasanuddin. 
Budiman, Arif. 2000. Teori Pembangunan Dunia Ketiga. Jakarta: PT Gramedia Pustaka Utama

Herman. (n.d). Kementrian Pertanian Republik Indonesia: Modernisasi Pertanian Jadi Andalan Kementan Menghadapi Globalisasi. Diakses pada bulan Juli, 2021, https://www.pertanian.go.id/home/?show=news\&act=view\&id=2267\#

Prayoga, K., Nurfadillah, S., Saragih, M., \& Riezky, A. M. (2019). Menakar Perubahan SosioKultural Masyarakat Tani Akibat Miskonsepsi Modernisasi Pembangunan Pertanian. Journal on Socio-Economics of Agriculture and Agribusiness, 13(1), 96-114.

Rifkian, B. E., Suharso, P., \& Sukidin, S. (2017). Modernisasi Pertanian (Studi Kasus Tentang Peluang Kerja Dan Pendapatan Petani Dalam Sistem Pertanian Di Desa Dukuhdempok Kecamatan Wuluhan Kabupaten Jember). JURNAL PENDIDIKAN EKONOMI: Jurnal Ilmiah Ilmu Pendidikan, Ilmu Ekonomi dan Ilmu Sosial, 11(1), 39-48.

Togatorop, A., \& Basri, B. (2017). Modernisasi Pertanian terhadap Pemakaian Pupuk dalam Meningkatkan Taraf Hidup Petani di Desa Sirisirisi Kecamatan Doloksanggul Sumatera Utara (Doctoral dissertation, Riau University).

Yulia, D. (2019). Revolusi hijau kebijakan ekonomi pemerintah bidang pertanian di Kanagarian Selayo tahun 1974-1998. HISTORIA: Journal of Historical Education Study Program, 4(2), 78-89. 